\title{
Game Battle of Artificial Intelligence Berbasis Android
}

\author{
Riandika Lumaris, Informatika Institut Sains dan Teknologi Terpadu Surabaya, \\ Hendrawan Armanto, Informatika Institut Sains dan Teknologi Terpadu Surabaya, \\ dan Willy Adrianus, Informatika Institut Sains dan Teknologi Terpadu Surabaya
}

\begin{abstract}
Abstrak - Dengan berkembangnya permainan dan artificial intelligence saat ini, maka dibuat sebuah permainan Battle of Artificial Intelligence. Game ini merupakan game berbasis Android dan merupakan permainan pertarungan antar robot, tetapi robot yang dijalankan berdasarkan pada sistem artificial intelligence yang dibuat oleh pemain. Dalam konsep ini pemain dapat membuat sebuah sistem Artificial Intelligence yang digunakan pada sebuah robot, dan robot tersebut akan digunakan untuk bertarung dengan robot musuh. Permainan ini merupakan permainan strategi dimana pemain diajak untuk memikirkan cara memenangkan pertempuran, yaitu dengan memilih prioritas dan membuat sistem AI yang berbeda. Pemain dapat mengembangkan, mengubah sebuah sistem Artificial Intelligence sesuai dengan yang pemain inginkan. Tidak hanya itu, pengguna juga dapat mengembangkan sistem AI yang dibuat dengan cara melakukan pertempuran dengan pemain lain secara online. Pemain dapat mengetahui sejauh mana sistem Artificial Intelligence yang dibuat mampu bertahan. Dari 22 pengguna yang sudah melakukan uji coba permainan dan mengisi kuisioner diperoleh bahwa konsep permainan ini menarik. Berdasarkan pemahaman tutorial, pengguna dapat menambah pengetahuan pengguna mengenai bagaimana artificial intelligence bekerja. Hampir $60 \%$ pengguna menyukai interface yang dibuat di dalam game. Pengguna juga dapat menambah pengetahuan mengenai pembuatan sistem artificial intelligence pada permainan ini berdasarkan hasil pemahaman sistem artifcial intelligence. Dengan adanya multiplayer, pengguna termotivasi untuk mengembangkan sistem artificial intelligence dengan bertanding dengan pemain lain secara online. Rating rata-rata yang diperoleh dari 22 pengguna yang telah melakukan uji coba adalah 3.45.
\end{abstract}

Kata Kunci - Android, Artificial Intelligence, Artificial Intelligence for Games, Game, Strategy

\section{PENDAhUluan}

$\mathrm{T}$ actical video game adalah genre game yang mengutamakan perencanaan dan pemikiran yang mahir untuk dapat memenangkan permainan. Biasanya tactical video game ini menggunakan lawan bermain komputer yaitu Artificial Intelligence yang disediakan oleh game. Pada permainan ini, pemain juga membuat artificial intelligence

Riandika Lumaris, Departemen Informatika, Institut Sains dan Teknologi Terpadu Surabaya, Jawa Timur, Indonesia (e-mail: riandika@stts.edu)

Hendrawan Armanto, Departemen Informatika, Institut Sains dan Teknologi Terpadu Surabaya, Jawa Timur, Indonesia (e-mail: hendrawan@stts.edu)

Willy Adrianus, Departemen Informatika, Institut Sains dan Teknologi Terpadu Surabaya, Surabaya, Jawa Timur, Indonesia. yang digunakan dalam pertarungan Artificial Intelligence. Artificial Intelligence for Games merupakan bagian atau kunci dari permainan ini.

Dengan adanya permainan ini maka pemain dapat mengetahui bagaimana Artificial Intelligence dapat bekerja dan bagaimana membuat sistem Artificial Intelligence itu sendiri dalam bentuk game. Permainan ini adalah permainan berbasis dari aplikasi game pada mobile device yang menggunakan sistem operasi Android dan merupakan permainan pertarungan antar robot dalam suatu arena yaitu antara robot pemain dan robot musuh. Pemain membuat sistem AI untuk robot yang mereka pertarungkan. Sistem AI yang dibuat oleh pemain dapat menjalankan robot. Tidak hanya itu pemain dapat membuat lebih dari satu sistem AI dan dapat diubah sesuai kebutuhan pemain. Fitur-fitur yang tersedia dalam permainan ini yaitu Sistem AI, Storymode, AI Editor, Tutorial, Battle Controls, Ally and Enemy, Difficulty Level, Achievement, Interaktif UI AI Editor, Multiplayer and Ranking Battle.

\section{TINJAUAN PUSTAKA}

Penelitian ini menggunakan beberapa tinjauan pustaka sebagai dasar agar penelitian dapat berjalan sesuai arah yang tepat. Tinjauan pustaka yang digunakan antara lain:

\section{A. Game}

Game merupakan suatu metode bermain yang digunakan untuk kesenangan ataupun sebagai alat pembelajaran (pendidikan) [1]. Seiring perkembangan teknologi, tantangan dari game terus ditingkatkan dengan memberikan gameplay baru ataupun fitur baru. Dan pada saat yang sama, game tersebut harus tetap menarik untuk dimainkan dan tidak memberi tantangan yang mustahil untuk dimainkan. Karena itu seiring dengan perkembangan teknologi, variasi game menjadi luas dan dikategorikan. Salah satu perkembangan game yang hingga saat ini terus berkembang adalah video games.

\section{B. Game Strategy}

Game strategy merupakan game yang berfokus pada pikiran dan rencana untuk mencapai kemenangan. Game strategy menekankan pada strategi yang dipakai, tactic dan logika. Pada game jenis ini, pemain harus merencanakan tindakan yang akan dilakukan berikutnya terhadap lawan atau tujuan untuk mencapai kemenangan pada game tersebut. Pada sebagian besar permainan genre strategy, pemain diberikan pandangan seperti ahli strategi yang mengontrol semua unit di permainan dan dikendalikan langsung oleh pemain. 


\section{Artificial Intelligence}

Artificial Intelligence (Kecerdasan Buatan) biasanya didefinisikan sebagai Intelligence Agents dimana mesin yang merasakan lingkungan dan mengambil tindakan yang mempunyai peluang besar untuk berhasil mencapai tujuannya [2]. Hingga saat ini, Artificial Intelligence tetap berkembang hingga mesin tersebut dapat meniru pemikiran manusia seperti belajar dan melakukan sebuah pemecahan masalah. Tujuan Artificial Intelligence dapat sederhana ataupun kompleks. Artificial Intelligence sering dipakai pada penggunaan algoritma. Banyak algoritma Artificial Intelligence mampu belajar dari data, Artificial Intelligence dapat meningkatkan kemampuannya dengan mempelajari strategi dan aturan yang telah bekerja atau menggabungkan beberapa algoritma yang berbeda.

Artificial Intelligence banyak digunakan pada permainan video, dimana pemain dapat bertanding melawan musuh yang biasanya disebut Computer atau AI. Computer atau AI tersebut juga dibagi berdasarkan tingkat kesulitannya. Setiap tingkatan pada Computer tersebut memiliki pemikiran yang berbeda terhadap langkah yang akan diambil berikutnya. Model Artificial Intelligence pada permainan dibagi menjadi tiga bagian yaitu Strategy, Decision making, dan Movement.

Behavior Tree merupakan model matematika dari rencana eksekusi yang digunakan dalam ilmu komputer, robotika, sistem kontrol dan permainan video. Secara tampilan, behavior tree direpresentaskan sebagai pohon yang memiliki nodes berbeda-beda. Perjalanan behavior tree dimulai dari root yang mengirimkan tanda-tanda dengan frekuensi tertentu ke child dari root ini. Tanda merupakan sinyal yang memungkinkan untuk menjalankan atau mengeksekusi child.

\section{Metode dan Inti Penelitian}

Berikut adalah langkah-langkah yang dilakukan dalam melakukan penelitian ini:

1. Pencarian sumber informasi terkait tactical game

2. Pencarian sumber informasi terkait AI for Games

3. Perancangan sistem Game

4. Pencarian resource pendukung

5. Perancangan sistem Artificial Intelligence

6. Melakukan ujicoba sistem Artificial Intelligence

7. Menggabungkan sistem game dan sistem artificial intelligence

8. Melakukan ujicoba sistem (alfa dan beta testing)

9. Publikasi game ke playstore

\section{A. Arsitektural Sistem}

Alur permainan yang dibuat pada permainan ini dimulai dari permintaan persetujuan pemain untuk mengakses perangkat pemain. Kemudian dilanjutkan pada loading dari permainan. Apabila pemain baru pertama kali menginstall aplikasi maka pemain wajib menyelesaikan tutorial dan lanjut ke tampilan main menu. Pada permainan ini terdapat enam menu yaitu story mode, multiplayer, tutorial, AI editor, settings, dan achievement. Pada story mode, pemain dapat memilih arena yang dimainkan dan setelah itu mengatur sistem AI pada robot yang digunakan untuk bertarung. Pada multiplayer terdapat tiga menu yaitu find match, history dan leaderboard. Find match digunakan untuk bertanding dengan pemain lain secara online. History digunakan untuk melihat pertandingan yang sudah selesai. Leaderboard digunakan untuk melihat ranking semua pemain yang pernah bermain.

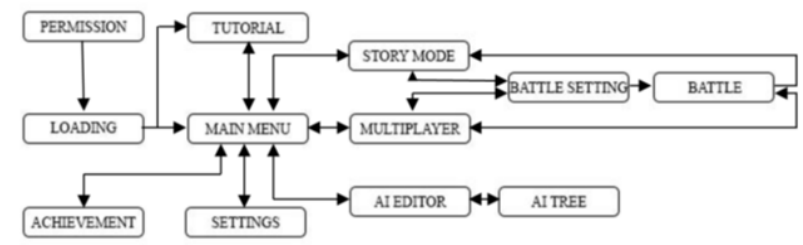

Gambar. 1. Alur Permainan

Pada tutorial berisi tiga tahap. Tahap pertama tutorial berisi pengenalan terhadap unit dan gameplay pada permainan ini. Tahap kedua tutorial berisi pengenalan terhadap sistem AI mulai dari cara kerja AI dan cara membuat sebuah node pada sistem AI. Tahap ketiga tutorial berisi pengenalan mengatur sistem AI pada robot yang ada pada arena. Pada AI editor berisi sistem AI yang telah dibuat oleh pemain. Pemain dapat membuat, mengubah, menghapus, mengganti nama dan duplicate sistem AI pada tampilan AI editor. Pada achievement, pemain dapat melihat achieve apa saja yang sudah didapat. Pada settings, pemain dapat mengatur suara background music dan sound effect permainan.

\section{B. Desain Interface}

Bagian ini akan menjelaskan beberapa tampilan yang ada pada permainan. Pada gambar 2 merupakan tampilan main menu yang berisi menu story mode, multiplayer, tutorial, ai editor, achievement dan settings.

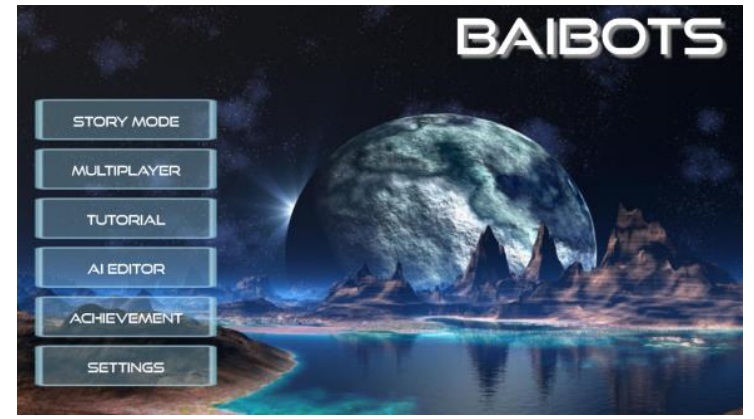

Gambar. 2. Tampilan Main Menu

Pada Gambar 3 merupakan tampilan battle dimana terdapat map arena yang digunakan untuk melihat jalannya pertempuran. Terdapat objective atau goal, waktu, skor dan battle controls. Pada battle controls terdapat tiga tombol yaitu tombol pause, tombol fast forward dan tombol skip. Ketika pertempuran berakhir, ditampilkan tombol replay dan tombol back to story mode.

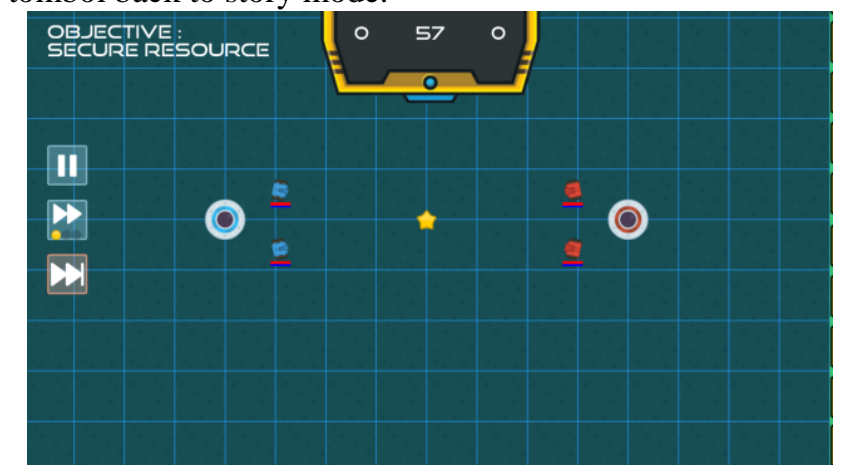

Gambar. 3. Tampilan Battle 
Pada Gambar 4 merupakan tampilan tutorial pendahuluan dimana tutorial ini mengenalkan pemain mengenai unit dan cara bermain permainan ini.

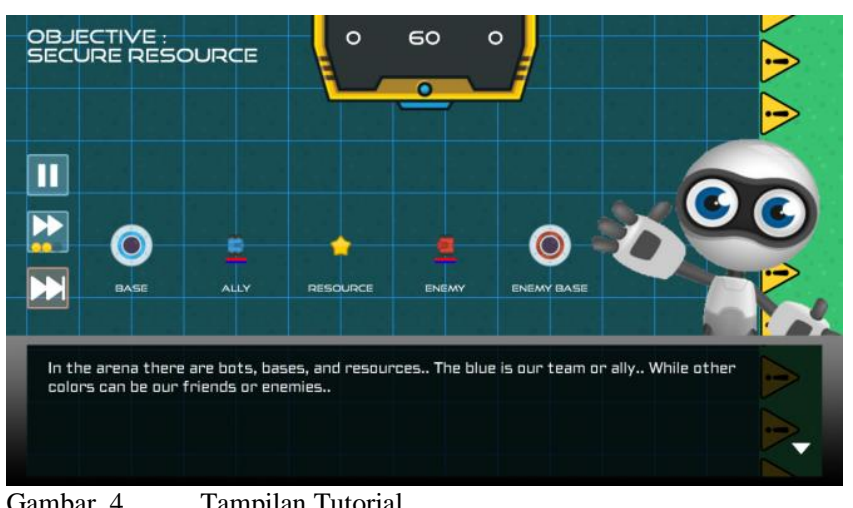

Pada Gambar 5 merupakan tampilan AI Tree dimana ditampilkan sistem AI yang telah dibuat. Pada tampilan ini, pemain dapat mengubah sistem AI dengan menambah, mengubah atau menghapus node. Pemain juga dapat melihat info node yang telah dibuat.

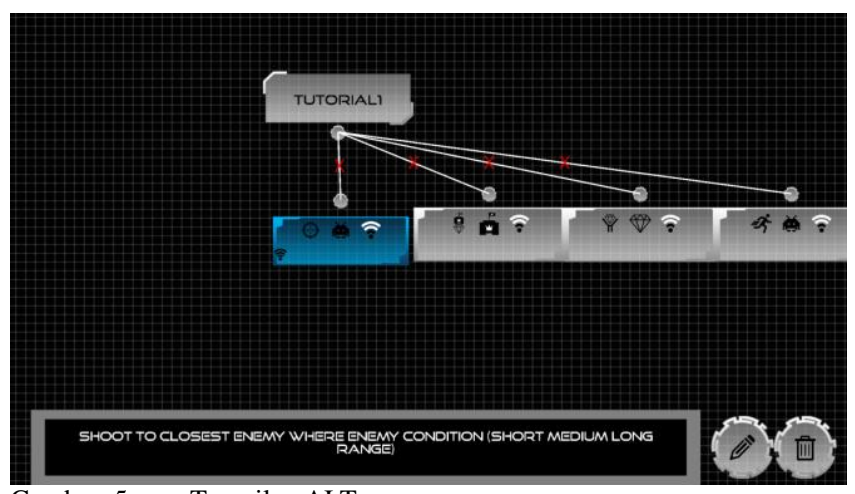

Gambar. 5. Tampilan AI Tree

\section{Sistem Artificial Intelligence}

Bagian ini akan membahas mengenai sistem artificial intelligence yang merupakan bagian utama dari permainan. Konsep sistem artificial intelligence yang dibuat berdasarkan konsep behavior tree. Dimana konsep behavior tree merupakan salah satu model yang banyak digunakan untuk membuat sebuah artificial intelligence dan sangat dikenal di kalangan game developer. Konsep sistem artificial intelligence ini secara grafik diimplementasikan dalam bentuk pohon dimana pohon tersebut mempunyai akar dan cabang ke segala arah yang nantinya disebut node. Konsep sistem artificial intelligence yang digunakan diubah sesuai dengan permainan yang dimainkan.

Untuk awal pembacaan konsep sistem artificial intelligence dimulai dari root dimana pada konsep sistem artificial intelligence (gambar 6) menggunakan judul artificial intelligence sebagai root. Root merupakan awal dari pencarian sebuah aksi yang akan dijalankan. Pada konsep sistem artificial intelligence tersebut, root berbentuk sebuah persegi panjang dengan pinggiran bulat dan pada permainan Battle Artificial intelligence akan disebut Root Node. Dari root akan dimulai mencari sebuah aksi yang dapat dijalankan dimulai dengan mencari pada bagian child dari root. Jika child yang dicari adalah sebuah aksi yang dapat dijalankan maka pencarian akan berhenti dan aksi tersebut akan dijalankan. Prioritas sebuah child pada konsep sistem artificial intelligence ini adalah posisi. Dimana posisi sebuah child diurutkan dari kiri ke kanan. Jika child pertama diperiksa dan hasilnya tidak dapat dijalankan maka sistem artificial intelligence akan memerika child berikutnya yaitu child kedua.

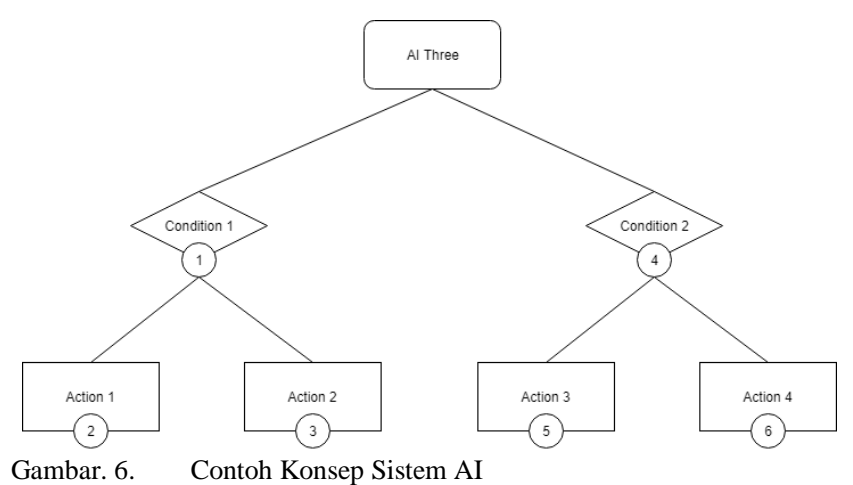

Konsep sistem artificial intelligence ini tidak membatasi jumlah child atau aksi yang akan dibuat bahkan jika child dari root memiliki child, tidak ada batasan jumlah yang harus dimiliki. Pencarian ini akan berulang hingga aksi yang dapat dijalankan ditemukan atau seluruh child telah diperiksa dan tidak ada yang dapat dijalankan maka pencarian akan berhenti. Jika ditemukan aksi yang dapat dijalankan maka aksi tersebut dijalankan. Jika tidak ditemukan aksi yang dapat dijalankan maka sistem artificial intelligence tidak akan menjalankan aksi apapun (idle). Pencarian dilakukan ulang setiap tick pada sistem artificial intelligence berjalan dan dimulai kembali dari root. Konsep sistem artificial intelligence ini berulang terus menerus selama sistem artificial intelligence masih berjalan. Pada konsep sistem artificial intelligence ini juga dapat dimanfaatkan dengan Logic Gate (Gerbang Logika). Dimana sistem artificial intelligence ini dapat melakukan kondisi OR dan AND di dalam satu sistem artificial intelligence.

Node sistem artificial intelligence dibagi menjadi empat bagian yaitu action node, decision node, connector node dan root node. Action node digunakan untuk menjalankan aksi yang dipilih pada robot. Action node berisi aksi, target, prioritas dan filter yang akan dijalankan. Aksi yang tersedia pada action node yaitu idle, move, flee, shoot, catch, drop dan secure. Target yang tersedia pada action node yaitu enemy, ally, our base, enemy base dan resource. Prioritas yang tersedia pada action node yaitu closest range, furthest range, lowest health, highest health, lowest shield dan highest shield. Filter yang tersedia pada action node yaitu carrying resource, short range, medium range, long range, out of range, $0-25 \%$ health, $25-50 \%$ health, $50-75 \%$ health, $75-100 \%$ health, $0-25 \%$ shield, $25-50 \%$ shield, $50-75 \%$ shield, $75-100 \%$ shield. Decision node digunakan untuk mencari apakah sebuah target ada atau tidak ada pada arena. Decision node juga digunakan untuk menentukan apakah node berikutnya dijalankan atau tidak. Connector node berisi target, prioritas, filter dan kondisi. Target yang tersedia pada decision node yaitu self, enemy, ally, resource, 
ally base, enemy base. Prioritas dan filter yang tersedia pada decision node seperti prioritas dan filter yang tersedia pada action node. Kondisi yang tersedia pada decision node yaitu exist or not exist. Connector node digunakan sebagai penghubung antar node. Root node digunakan sebagai awal dari proses pencarian sebuah aksi yang dijalankan atau penghubung dengan sistem artificial intelligence lainnya.

Sistem artificial intelligence pada permainan ini didukung dengan penggunaan nama untuk setiap sistem artificial intelligence yang berbeda serta dapat diubah setiap saat. Sistem artificial intelligence pada permainan ini juga didukung dengan fitur duplicate dimana sebuah sistem artificial intelligence dapat dicopy menjadi lebih dari satu. Dengan adanya fitur duplicate ini, pemain dapat menggunakannya sebagai fungsi backup and restore ataupun sistem version untuk mengembangkan sistem artificial intelligence yang pemain telah buat. Sistem artificial intelligence pada permainan ini tidak memiliki batasan berapa banyak sistem artificial intelligence yang dapat dibuat.

Pada permainan ini, pemain perlu memikirkan strategi yang dilakukan dalam memenangkan pertempuran. Pada permainan ini, terdapat 10 arena dengan tingkat kesulitan yang berbeda. Setiap arena memiliki jumlah yang berbeda atau posisi bot yang berbeda. Dengan posisi masing-masing bot yang berbeda di setiap arena, pemain dapat membuat sistem AI yang berbeda dengan memprioritaskan aksi yang berbeda. Dengan strategi, pemain dapat memenangkan pertempuran yang sebelumnya belum dimenangkan.

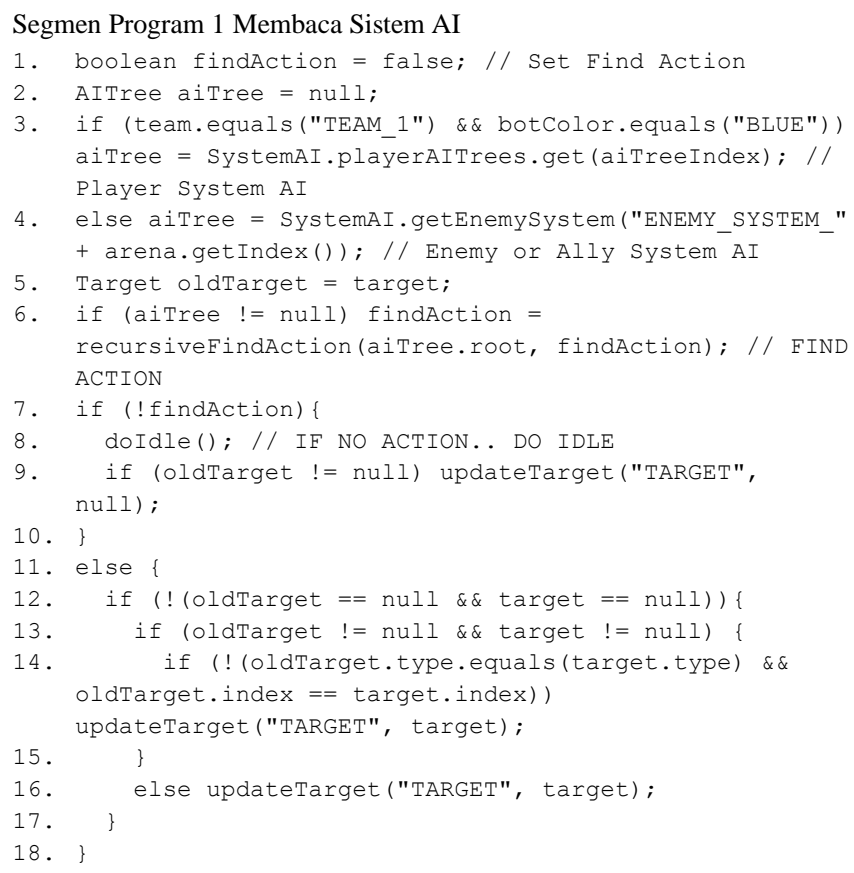

Segmen program 1 merupakan program untuk pembacaan sistem Artificial Intelligence. Segmen program ini dijalankan ketika pertandingan telah dimulai dan setiap bot akan membaca sistem AI masing-masing. Sedangkan segmen program 2 mengenai pencarian aksi pada sistem Artificial Intelligent. Segmen program ini dijalankan ketika membaca sistem AI.

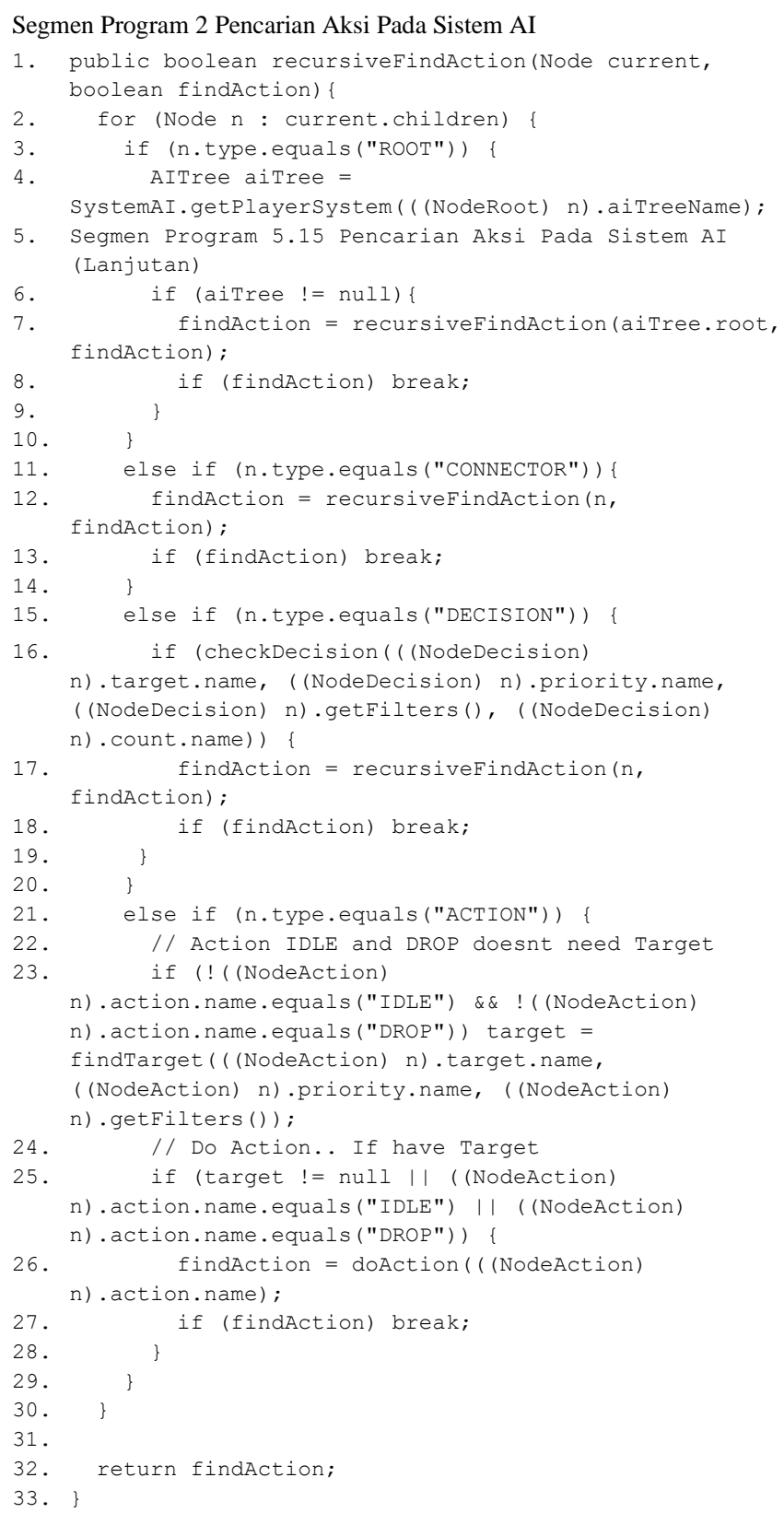

\section{UJI COBA}

Bagian ini akan menjelaskan hasil uji coba kuisioner yang diberikan kepada pengguna setelah mencoba permainan yang telah dibuat. Pertanyaan yang ditanyakan mulai dari pemahaman tutorial, konsep dan gameplay permainan, serta rating keseluruhan permainan.

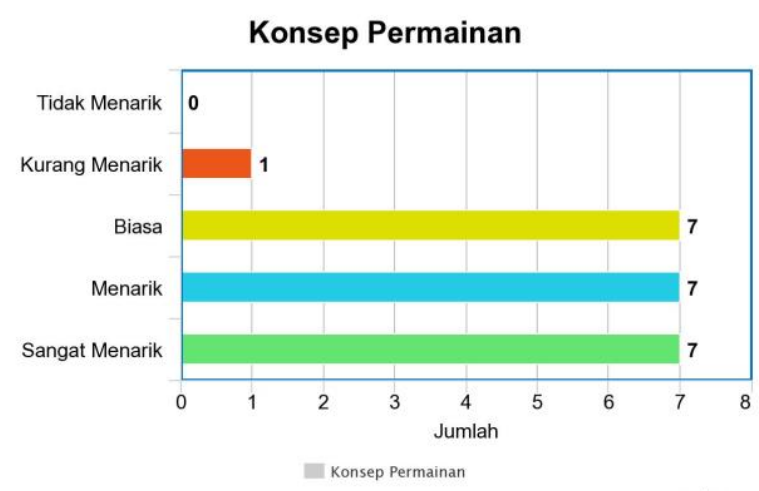

Gambar. 7. Konsep Permainan 
Pada Gambar 7 adalah pertanyaan mengenai nilai konsep (gameplay) dari permainan ini. Hasil yang didapatkan berada pada tingkatan biasa, menarik, dan sangat menarik dengan jumlah yang sama 7 dari 22 orang yang telah mengisi kuisioner. Sedangkan pada Gambar 8 adalah pertanyaan mengenai pemahaman cara bermain melalui tutorial yang disediakan pada permainan ini. Hasil yang didapatkan berada pada tingkatan biasa dengan jumlah 11 dari 22 orang yang telah mengisi kuisioner.

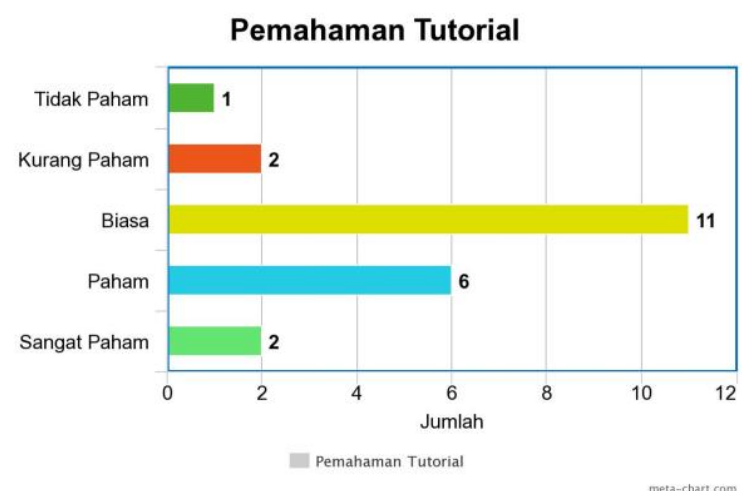

Gambar. 8.

Pemahaman Tutorial

Pada Gambar 9 adalah pertanyaan mengenai tampilantampilan yang terdapat pada permainan ini. Hasil tampilan yang didapatkan berada pada tingkatan biasa dengan $42.7 \%$ dari penilaian 22 orang yang telah mengisi kuisioner.

\section{Interface}

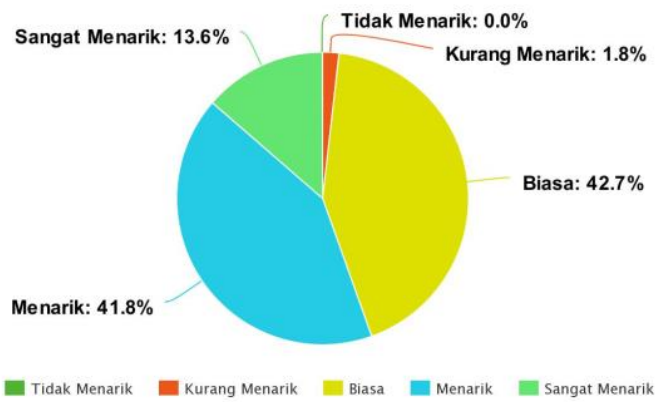

Gambar. 9. Interface

Pada Gambar 10 adalah pertanyaan mengenai konsep, rancangan, dan pembuatan sistem artificial intelligence yang terdapat pada permainan ini. Hasil yang didapatkan berada pada tingkatan biasa dengan jumlah 12 dari 22 orang yang telah mengisi kuisioner.

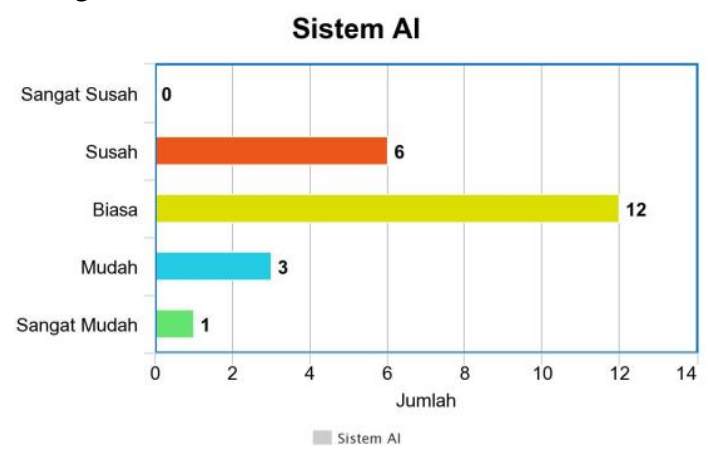

Gambar. 10

Sistem Artificial Intelligence

Pada Gambar 11 adalah pertanyaan mengenai rating secara keseluruhan permainan ini. Rating yang didapatkan yaitu 3.45 dari 22 orang yang telah mengisi kuisioner.

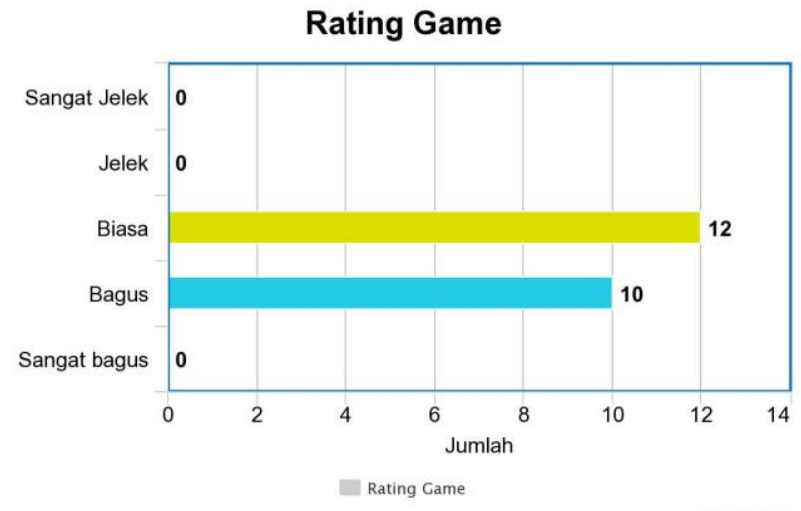

Gambar. 11. Rating Game

\section{KESIMPULAN}

Kesimpulan yang diperoleh melalui penelitian ini adalah sebagai berikut:

1. Dengan penggabungan konsep strategi dan artificial intelligence, pengguna dapat memahami bagaimana musuh yang menggunakan artificial intelligence sebagai metode permainan memperoleh sebuah kemenangan di dalam permainan.

2. Game ini dapat menambah pengetahuan kepada pengguna terhadap rancangan Artificial Intelligence, cara sebuah Artificial Intelligence bekerja, dan pengguna mampu membuat sebuah sistem Artificial Intelligence bekerja melalui permainan atau program ini yang dibuktikan dengan hasil kuisioner pada tingkat pemahaman tutorial dan pemahaman sistem Artificial Intelligence.

3. Game ini dapat memberikan motivasi kepada pengguna untuk bersaing mengembangkan sebuah sistem Artificial Intelligence dengan bertarung dengan pengguna lain secara online.

\section{DAFTAR PUSTAKA}

[1] Horton, John. 2015. Android Game Programming. Packt Publishing.

[2] Millington, Ian. \& Funge, John. 2009. Artificial Intelligence for Games. United States of America: Morgan Kaufman Publishing.

[3] Horton, John. 2015. Learning Java by Building Android Games. Packt Publishing.

[4] Getting Started in Android [Online]. Available at: https://developer.android.com/training/index.html [Accessed 18 Mei 2017]

[5] Cho, James. 2014. The Beginner's Guide to Android Game Development. Glasnevin Publishing.

[6] Horton, John. 2015. Android Programming for Beginners. Packt Publishing.

[7] Info AI Decision Tree [Online]. Available at: https://www.aihorizon.com/essays/generalai/decision_trees.htm [Accessed 18 Mei 2017]

[8] Buckland, Mat. 2005. Programming Game AI by Example. Wordware Publishing.

[9] Norvig, Peter. \& Russel, Stuart J. 2016. Artificial Intelligence: A Modern Approach. Pearson Publishing.

[10] Bourg, David. \& Seemann, Glenn. 2014. AI for Game Developers O’Reilly Publishing.

Riandika Lumaris lahir di Surabaya, Indonesia, pada tahun 1992. Menyelesaikan studi S1 di program studi Teknik Informatika STTS pada tahun 2014. Menyelesaikan studi masternya pada program studi Teknologi Informasi STTS pada tahun 2016. Minat penelitian adalah pada bidang Web Technologies, Cloud Computing, dan E-Commerce. 